\title{
Rapšu el̦as degvielas patēriņa un izmešu emisijas pētījumi, iesmidzinot ūdens-bioetanola maisījumu motora ieplūdes sistēmā The Rapeseed Oil Fuel Consumption and Exhaust Emissions Research Injecting a Water-Bioethanol Blend in the Engine Intake System
}

\author{
Aivars Birkavs*, Ilmārs Dukulis, Gints Birzietis \\ LLU Spēkratu institūts \\ Motor Vehicle Institute, LLU
}

\begin{abstract}
A research on the $\mathrm{NO}_{\mathrm{x}}$ reduction potential in diesel engine emissions injecting a 50\% water-bioethanol blend in the engine intake system was carried out. Experiments were conducted on the test bench equipped with an Opel 16 DA four-cylinder 1.6-litre diesel engine and a two-tank system to run the engine on rapeseed oil. Toxic emissions were estimated using AVL SESAM FTIR multicomponent exhaust gas analytical system; the fuel consumption was measured using Kern 440-49A electronic weighing system. Three repetitions at the $1500 \mathrm{~min}^{-1}$ and $2500 \mathrm{~min}^{-1}$ engine crankshaft rotational speeds were performed; duration of each repetition 120 seconds. Investigation results showed that such approach can reduce the nitrogen oxide content in exhaust gases by $32 \%$, without significantly affecting other toxic emissions, at the same time reducing fuel consumption by $16-21 \%$. Both rapeseed oil fuel and additive WE50 were derived from renewable resources, which plays an important role in elimination of climate changes.
\end{abstract}

Key words: Rapeseed oil fuel, exhaust emissions, diesel engine, bioethanol.

\section{Ievads}

Ar dīzel̦motoriem ir aprīkota lielākā daḷa komerctransporta un lauksaimniecības tehnikas, kā arī daudzi vieglo automobil̦u model̦i. Attīstoties tehnoloǵijām, augu eḷıa tîrā veidā un maisījumos ar fosilo dīzel̦degvielu arvien vairāk tiek pielietota kā dīzel̦motoru degviela gan Eiropā, gan arī Latvijā.

Augu ellıu, kas atbilst ES un LV pieņemto standartu prasībām, var lietot dīzel̦motoros ilgstoši, un tā neizraisa motora vai tā sistēmu bojājumus. Transporta līdzekḷus, kuru motori aprīkoti darbināšanai ar rapšu ellıu un tās maisījumiem ar fosilo dīzel̦degvielu, var ekspluatēt arī ziemā līdz pat $-25{ }^{\circ} \mathrm{C}$ (Dukulis, Birkavs, \& Birzietis, 2010).

Analizējot augu elılas degvielas izmantošanas pētījumus pasaulē, var secināt, ka dažādās publikācijās sniegtie rezultāti, kas attiecas uz jaudas, degvielas patēriņa un atgāzu sastāva izmaiṇām, ir ļoti atšksirīgi. Tas atzīmēts arī Francijā veiktajā 62 pētījumu apskatā (Sidibe, Blin, Vaitilingom, \& Azoumah, 2010), kur par galveno nesakritību cēloni minētas atšksirības pētījumos izmantotās eḷıas kvalitātē, pētîjumu apstākḷlos, lietotajās mērierīcēs un motoru tipos. Tas aktualizē pētījumu veikšanu katrā valstī, t.sk. Latvijā, balstoties tieši uz konkrētā reǵiona klimatiskajiem apstākḷiem, uz vietas saražoto eḷıu un raksturīgākajiem spēkratu un motoru veidiem. Sevišķi tiek akcentēta summāro mono-slāpekḷa oksīdu $\mathrm{NO}_{\mathrm{x}}$ (NO un $\mathrm{NO}_{2}$ summas) emisija, kas mūsdienās ir kḷuvusi par vienu no bīstamākajiem vides piesārņojuma faktoriem Eiropā.

Slāpekḷa oksīdi veidojas dīzel̦motoru darbības rezultātā, degvielai sadegot augstā temperatūrā, - vispirms rodas slāpekḷa monoksīds, tālāk, tam reaǵējot ar skābekli, veidojas slāpekḷa dioksīids. Atmosfērā slāpekḷa dioksīds reaǵē ar ūdeni, veidojot skābos nokrišņus, kas negatīvi ietekmē augu valsti, celtnes, metāla izstrādājumus, kā arī tehniku.

Latvijā veiktie pētījumi par rapšu ellas degvielas izmešu sastāvu liecina, $\mathrm{ka} \mathrm{NO}_{\mathrm{x}}$ saturs atgāzēs dažādos spēkratu ekspluatācijas režīmos palielinās vidēji par 30\% (Dukulis, Pirs, Jesko, Birkavs, \& Birzietis, 2009).

Lietuvā veiktajos tiešās iesmidzināšanas $59 \mathrm{~kW}$ motora $D$-243 stenda izmēǵinājumos konstatēts, ka $\mathrm{NO}_{x}$ daudzums atgāzēs, motoru darbinot ar tīru rapšu ellıu, ir par 9.2\% lielāks nekā to darbinot ar fosilo

\footnotetext{
* Corresponding author's email: 
dīzeḷdegvielu. Savukārt CO (oglekḷa monoksīda) emisija samazinās par 40.5\%, arī nesadegušo og̣̦ūdeņražu daudzums nedaudz samazinās, bet $\mathrm{CO}_{2}$ saturs atgāzēs nedaudz palielinās (Labeckas \& Slavinskas, 2005; 2009).

Vācijā, ar mērķi noteikt atgāzu sastāva atbilstību Eiropas Savienības dīzel̦motoru emisijas standartiem, uz stenda testēts Deutz-Fahr traktors. Šo pētījumu rezultāti apliecina, ka $\mathrm{CO}, \mathrm{HC}$ (nesadegušo og̣̦ūdeņražu) un mehānisko piemaisījumu (cieto dalıiņu) daudzums izplūdes gāzēs atbilst emisijas standartiem, bet $\mathrm{NO}_{\mathrm{x}}$ daudzums, lietojot rapšu ellıu, par 14\% pārsniedz limitējošās prasības (Thuneke, 2006).

Turcijā veiktajā viencilindru dīzeḷmotora Rainbow-186 stenda pētijumā salīdzināta fosilā dīzel̦degviela, RE20 (20\% rapšu eḷ las un $80 \%$ fosilās dīzel̦degvielas) un RE50 (50\% rapšu ellıas un $50 \%$ fosilās dīzeļdegvielas) maisījumi. Eksperimenti veikti ar degvielas sildīšanu un bez tās. Negaidīts rezultāts bija maisījumdegvielu $\mathrm{NO}_{x}$ satura samazinājums atgāzēs, salīdzinot ar dīzeļdegvielu. Arī CO saturs, izmantojot RE20 un RE50, bija zemāks, bet dūmainība augstāka. Degvielas uzsildīšana $\mathrm{NO}_{x}$ emisiju palielināja par 15-19\%, CO emisiju samazināja par 16-25\%, bet dūmainību samazināja par 9-26\% (Hazar \& Aydin, 2010).

Šveicē slogošanas stenda izmēǵinājumos pētîta lieljaudas $335 \mathrm{~kW}$ sešcilindru motora darbība ar fosilo dīzel̦degvielu, RME (rapšu elıılas metilesteri), sojas ellıu un rapšu ellıu (Soltic, Edenhauser, Thurnheer, Schreiber, \& Sankowski, 2009). Motors bija aprīkots ar elektroniski vadāmu ,sūknis-sprausla" tipa tiešās iesmidzināšanas sistēmu, turbokompresoru ar starpdzesētāju un ar ūdeni dzesējamu izplūdes gāzu recirkulācijas (EGR) sistēmu. Sojas elılas un rapšu ellıas priekšuzsildīšanai izmantoti infrasarkano staru radiatori. Mainīgie parametri eksperimentos bija iesmidzināšanas spiediens, moments un ilgums, kā arī izplūdes gāzu recirkulācijas pakāpe. Neskatoties uz to, ka RME un abu ellı tilpuma siltumspēja bija par 5-6\% zemāka nekā fosilajai dīzeļdegvielai, gan ar iesmidzināšanas parametru maiņu, gan bez tās visos slogošanas režīmos motors attīstīja lielāku griezes momentu, taču $\mathrm{NO}_{x}$ saturs izplūdes gāzēs būtiski palielinājās. Mainot EGR sistēmas parametrus tā, lai $\mathrm{NO}_{x}$ emisija tiktu saglabāta fosilās dīzel̦degvielas līmenī, rapšu eḷıas izmantošanas efektivitāte samazinājāas. RME, sojas un rapšu ellıas izmantošanas gadījumos konstatêts kopējo nesadegušo oglūūeņražu un oglekḷa monoksīda emisijas samazinājums, salīdzinot ar dìzeḷdegvielu. Veicot mērījumus aiz izplūdes sistēmas keramiskā katalizatora, emisijas samazinājās praktiski līdz nullei visām degvielām.

Veicot $72 \mathrm{~kW}$ viencilindra Elbewerk Roblau tiešās iesmidzināšanas motora $1 V D S 18 / 15$ pētījumus, vācu pētnieki (Paulsen, Wichmann, Schuemann, \& Richter, 2011) konstatēja, ka, darbinot motoru ar rapšu eḷıu, $\mathrm{NO}_{\mathrm{x}}$ saturs izmešos ir lielāks, bet nesadegušo og̣̦ūdeņražu saturs mazāks, salīdzinot ar fosilo dīzeļdegvielu. CO koncentrācija izplūdes gāzēs darbā ar ellıu ir palielināta tikai mazas motora noslodzes gadījumā, kā cēlonis ir nepilnīga ellıas sadegšana.

Slovākijā veikti rapšu ellıas degvielas pētījumi, par izmēginājumu objektiem izmantojot ar divu degvielas tvertņu sistēmu aprīkotus automobiļus 2000. gadā ražotu Škoda Octavia 1.9 TDI un 2007. gadā ražotu $V W$ Touareg R5 $2.5 U I$ (Kleinová, Vailing, Lábaj, Mikulec, \& Cvengroš, 2011). Izplūdes gāzu analīzei izmantota MAHA MGT 5 ierīce. CO saturs izplūdes gāzēs bija tuvs nullei visos testu režīmos. Nesadegušajiem ogl̦ūdeņražiem (HC) Škoda Octavia konstatēta tendence palielināties, $V W$ Touareg - samazināties. Savukārt $\mathrm{NO}_{\mathrm{x}}$ saturs Škoda Octavia samazinājās vidēji par aptuveni $40 \%$, bet $V W$ Touareg - par $10 \%$. Visas minētās atšķirības raksta autori izskaidro ar automobilu motoru un degvielas iesmidzināšanas sistēmu atšksirīgo konstrukciju.

Lai mazinātu slāpekḷa oksīdu veidošanos dīzel̦motora izmešos, līdzšinējos pētījumos sadegšanas temperatūras samazināšanai kā risinājums izmantots ūdens, kuru iesmidzina motora cilindrā degvielas iesmidzināšanas perioda beigās. Šāds process pazemina degvielas patēriņu līdz 2\%, kā arī samazina $\mathrm{NO}_{\mathrm{x}}$ un nesadegušo og̣̦ūdeņražu daudzumu atgāzēs (Markov, Bashirov, \& Gabitov, 2002), taču, iesmidzinot noteiktu ūdens daudzumu, novērota nestabila dīzeļmotora darbība. Analizētie pētijumi rāda, ka ūdens iesmidzināšana motora cilindrā var tikt veikta gan caur degvielas sprauslām, gan pa atsevišķu smidzinātāju ieplūdes kolektorā. Taču šim procesam ir būtisks trūkums - sistēmu var pielietot tikai apstākḷos, kad apkārtējās vides temperatūra ir lielāka par $0{ }^{\circ} \mathrm{C}$.

Tāpēc tika izveidots $50 \%$ (pēc tilpuma) ūdensbioetanola maisijums WE50, kuru var pielietot transporta līdzekḷu dīzeḷmotoros visu gadu, jo tā sasalšanas temperatūra ir $-40{ }^{\circ} \mathrm{C}$. Eksperimentālās priekšizpētes iekārtas motoram tika izveidota sprauslu sistēma ar regulējamu WE50 iesmidzināšanas daudzumu, lai, veicot mērījumus, varētu konstatêt optimālos režīmus $\mathrm{NO}_{\mathrm{x}}$ samazināšanai, būtiski nepalielinot citu toksisko izmešu emisiju. 


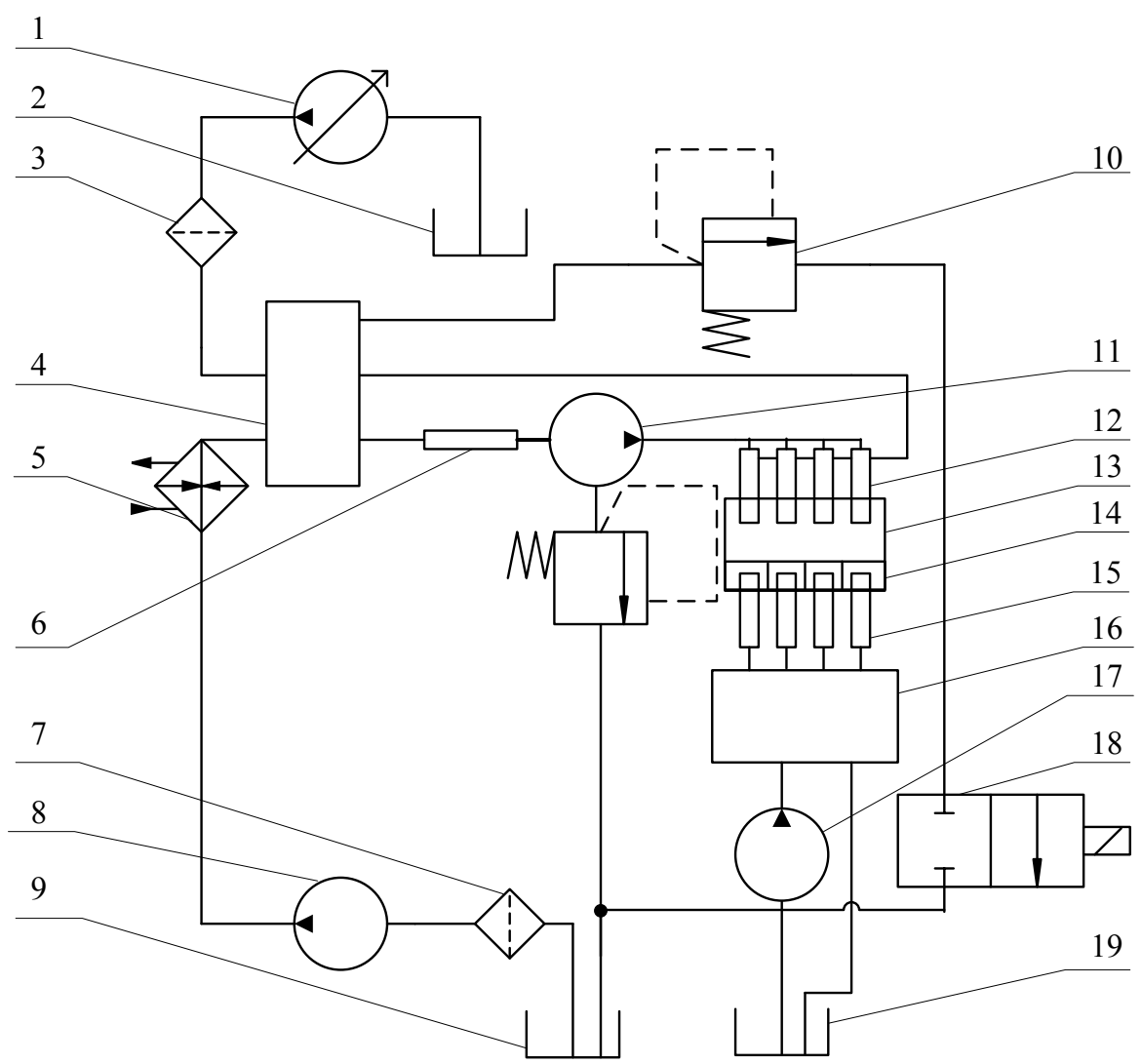

1. att. Eksperimentālās iekārtas principiālā shēma:

1, 8, 17 - elektriskie sūkņi; 2 - fosilās dīzel̦degvielas tvertne; 3, 7 - filtri; 4 - degvielas sadalītājs; 5 - siltummainis; 6 - stikla caurulīte; 9 - rapšu elıllas tvertne; 10 - vienvirziena vārsts;

11 - degvielas augstspiediena sūknis; 12 - degvielas sprauslas; 13 - dīzeḷmotors; 14 - ieplūdes kolektors;

15 - WE50 smidzinātāji; 16 - WE50 iesmidzināšanas sistēmas sadalītājs-regulators;

18 - elektromagnētiskais pretvārsts; 19 - WE50 tvertne.

Fig. 1. Principal scheme of the experimental equipment:

1, 8, 17 - electric pumps; 2 - fossil fuel tank; 3, 7 - filters; 4 - fuel distributor; 5 - heat exchanger; 6 - glass tube; 9 - rapeseed oil tank; 10 - one-way valve; 11 - high-pressure fuel pump; 12 - fuel nozzles; 13 - diesel engine; 14 - intake manifold; 15 - WE50 sprayers; 16 - distributor-regulator of WE50 injection system; 18 - electromagnetic valve; 19 - WE50 tank.

Pētījuma mērķis - novērtēt ūdens-bioetanola maisījuma pielietošanas potenciālu dīzel̦motora izmešu sastāva optimizēšanai, vienlaikus nosakot degvielas patēriņa izmaiņas.

\section{Materiāli un metodes}

Pētījuma gaitā par degvielu tika izmantota tīra rapšu ellıa un par piedevu gaisam ieplūdes kolektorā - WE50 (50\% ūdens-bioetanola maisījums). Eksperimenti tika veikti uz dīzel̦motora stenda, kas aprīkots ar Opel $16 \mathrm{DA}$ vienrindas četru cilindru $O H C$ dīzel̦motoru. Motora darba tilpums $1598 \mathrm{~cm}^{3}$; kompresijas pakāpe - 23; jauda - $40 \mathrm{~kW}$. Motora degvielas sistēmā izmantots augstspiediena sūknis Bosch VE 4/9R215, kas nodrošina sprauslu atvēršanās spiedienu līdz 135 bar. Motors aprīkots ar divu tvertņu sistēmu motora darbināšanai ar rapšu ellı. Š S̄i sistēma nodrošina degvielas temperatūru $85-87{ }^{\circ} \mathrm{C}$, kurā visām dīzel̦motoru degvielām viskozitāte ir līdzīga. Piedevas WE50 iesmidzināšanas daudzuma regulācija nodrošināta ar izveidotās sprauslu sistēmas palīdzību. WE50 iesmidzināšanas sistēma sastāv no sadalītājaregulatora, sūkņa, tvertnes un četriem smidzinātājiem, kas novietoti ieplūdes kolektorā pretī katram cilindram. Eksperimentālās iekārtas principiālā shēma parādīta 1. attēlā.

Eksperimenti veikti LLU Tehniskās fakultātes Alternatīvo degvielu zinātniskajā laboratorijā (ADZL). Toksisko izmešu noteikšanai izmantota 


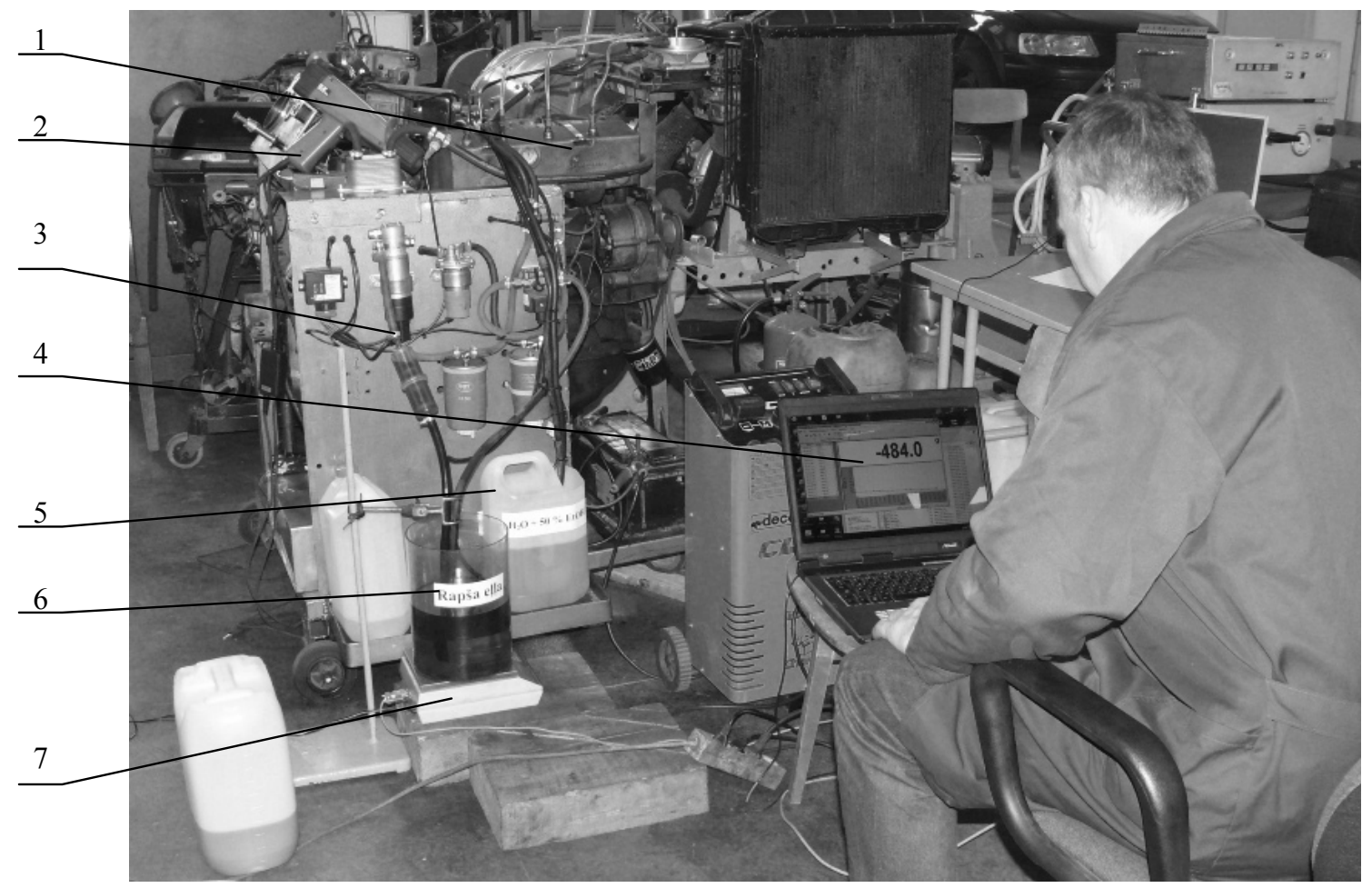

2. att. Eksperimentālā iekārta:

1 - WE50 iesmidzināšanas sistēma; 2 - stroboskops $D G 85$;

3 - ar divu tvertņu sistēmu aprīkots motorstends; 4 - degvielas patēriṇa datu reǵistrācijas dators; 5 - rapšu ellas tvertne; 6 - WE50 tvertne; 7 - svari Kern 440-49A.

Fig. 2. The experimental equipment:

1 - WE50 injection system; 2 - stroboscope DG 85; 3 - diesel engine test bench equipped with a two-tank system; 4 - fuel consumption registration PC; 5 - rapeseed oil tank;

6 - WE50 tank; 7 - Kern 440-49A weighing system.

AVL SESAM FTIR atgāzu analītiskā sistēma, kas paredzēta gan ottomotoru, gan dīzel̦motoru atgāzu komponenšu mērīšanai dažādos motora darbības režīmos. Atgāzu sastāvs tiek noteikts ar infrasarkano staru spektrometra palīdzību. Ar šo iekārtu var noteikt 27 dažādas atgāzu komponentes. Galvenās no tām ir: $\mathrm{CH}_{4}$ (metāns), $\mathrm{CO}_{2}, \mathrm{CO}, \mathrm{NO}_{x}$, dīzel̦motoros nesadegušie og̣̦ūdeņraži (angliski hydrocarbons diesel jeb HCD) un mehāniskās daḷiņas (angliski mechanical particles jeb MP). Ar AVL atgāzu analītisko sistēmu var mērīt un reǵistrēt atgāzu sastāvu gan brīvgaitas, gan arī dažādos kustības un slodzes režīmos. Nepārtrauktās mērīšanas režīmā iekārta var darboties 60 minūtes (AVL Emission ..., 2007).

Degvielas patērina noteikšanai tika izmantoti elektroniskie svari Kern 440-49A ar mērīšanas diapazonu līdz $6000 \mathrm{~g}$ un precizitāti $0.1 \mathrm{~g}$.

Pirms eksperimentu uzsākšanas tika pievienots atgāzu nosūcējs ar uzstādītu AVL SESAM FTIR atgāzu analizatora uztveršanas zondi un stroboskops Strobotester DG85 motora kloķvārpstas apgriezienu kontrolei (2. att.). Pēc sagatavošanās darbu veikšanas motors tika iedarbināts un uzsildīts ar fosilo dīzel̦degvielu līdz $85-87^{\circ} \mathrm{C}$ darba temperatūrai.

Testi tika veikti saskaņā ar iepriekšējos pētījumos izstrādāto metodiku (Birkavs \& Dukulis, 2011), kurā bija noskaidrots, ka kvalitatīvu rezultātu iegūšanai jāveic trīs 120 sekunžu atkārtojumi, ja motora kloķvārpstas rotācijas ātrums ir 1500 un 2500 apgriezienu min $^{-1}$.

Vispirms tika veikti atgāzu un degvielas patēriņa mērījumi, dīzel̦motoram darbojoties ar rapšu elııu bez WE50 piedevas. Pēc tam pakāpeniski tika iesmidzināta piedeva ieplūdes kolektorā ar ražīgumu no 0 līdz $45 \mathrm{~g} \mathrm{~min}^{-1}$, kas atbilst 0 līdz 1.86\% no ieplūstošā gaisa masas. Visas atgāzu komponentes mērītas ppm (no angḷu val. parts per million - daļiņas uz miljonu) mērvienībās, kas SI sistēmā atbilst $\mathrm{mg} \mathrm{kg}{ }^{-1}$. 
Toksisko izmešu saturs atgāzēs, $\mathrm{mg} \mathrm{kg}^{-1}$

The content of toxic emissions in exhaust gases, $\mathrm{mg} \mathrm{kg}^{-1}$

\begin{tabular}{|c|c|c|c|c|c|c|}
\hline $\begin{array}{c}\text { WE50 } \\
\text { saturs / content, } \\
\%\end{array}$ & $\mathrm{NO}_{x}$ & $\mathrm{MP}^{*}$ & $\mathrm{CH}_{4}$ & $\mathrm{HCD}^{* *}$ & $\mathrm{CO}_{2}$ & $\mathrm{CO}$ \\
\hline \multicolumn{7}{|c|}{$1500 \mathrm{~min}^{-1}$} \\
\hline 0.00 & 105.4 & 29.5 & 4.8 & 204.9 & 27264.1 & 1087.0 \\
\hline 0.35 & 71.1 & 110.5 & 23.1 & 57.5 & 27344.1 & 1885.4 \\
\hline 1.05 & 57.3 & 172.2 & 44.1 & 0.0 & 26908.8 & 2509.6 \\
\hline \multicolumn{7}{|c|}{$2500 \mathrm{~min}^{-1}$} \\
\hline 0.00 & 153.5 & 11.4 & 2.7 & 136.6 & 29620.8 & 646.8 \\
\hline 0.22 & 119.1 & 61.1 & 9.0 & 33.2 & 29428.3 & 1054.9 \\
\hline 0.63 & 104.4 & 95.8 & 20.1 & 0.0 & 28801.6 & 1434.6 \\
\hline 1.04 & 94.2 & 122.2 & 28.4 & 0.0 & 28585.8 & 1680.9 \\
\hline 1.46 & 76.1 & 169.8 & 43.7 & 0.0 & 27505.3 & 2220.2 \\
\hline 1.86 & 64.4 & 195.0 & 59.1 & 0.0 & 27134.3 & 2609.2 \\
\hline
\end{tabular}

MP* - mehāniskās daļiņas / mechanical particles.

HCD** - dīzeḷmotoros nesadegušie oglūūeņraži / hydrocarbons diesel.

\section{Rezultāti un diskusija}

Pirmie testi tika veikti, motora kloķvārpstai izdarot 1500 apgriezienus minūtē (1. tabula). Testa rezultāti uzskatāmi parāda, ka $\mathrm{NO}_{\mathrm{x}}$ un $\mathrm{HCD}$ samazinās, palielinot piedevas WE50 iesmidzināšanas daudzumu. $\mathrm{CO}_{2}$ daudzums paliek gandrīz nemainīgs, bet $\mathrm{CO}$ un MP saturs atgāzēs palielinās. Vērā ņemams fakts ir tas, ka, neskatoties uz nelielo $\mathrm{CH}_{4}$ (metāna) daudzuma palielināšanos, kopējais og̣̦ūdeņražu saturs atgāzēs būtiski samazinājās.

Iesmidzinot $1.05 \%$ WE50, mērījumi tika pārtraukti, jo vairāk nekā divas reizes palielinājās CO un mehānisko daļiņu saturs atgāzēs (3. att.). Līdz ar to, motora kloķvārpstai veicot 1500 apgriezienus minūtē, par efektīvāko tika konstatēts $0.35 \%$ WE50 piejaukums ieplūdes gaisam.
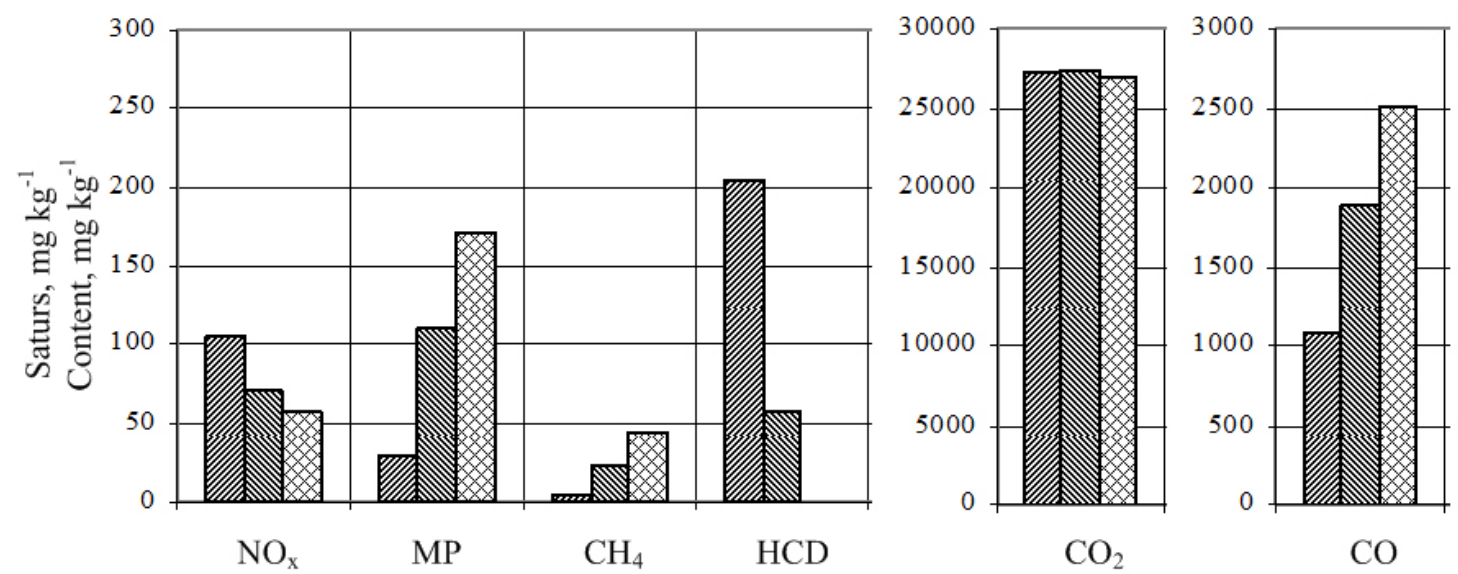

WE50 saturs/content $0 \% \mathbb{Q}$ WE50 saturs/content $0.35 \%$ WE50 saturs/content $1.05 \%$

Toksisko izmešu komponente

Toxic emission component

Paskaidrojums. MP - mehāniskās daļiņas; HCD - dīzel̦motoros nesadegušie ogḷūdeṇraži.

Explanation. MP - mechanical particles; HCD - hydrocarbons diesel.

3. att. Toksisko izmešu saturs atgāzēs pie $1500 \mathrm{~min}^{-1}$.

Fig. 3. The content of toxic emissions in exhaust gases at $1500 \mathrm{~min}^{-1}$. 


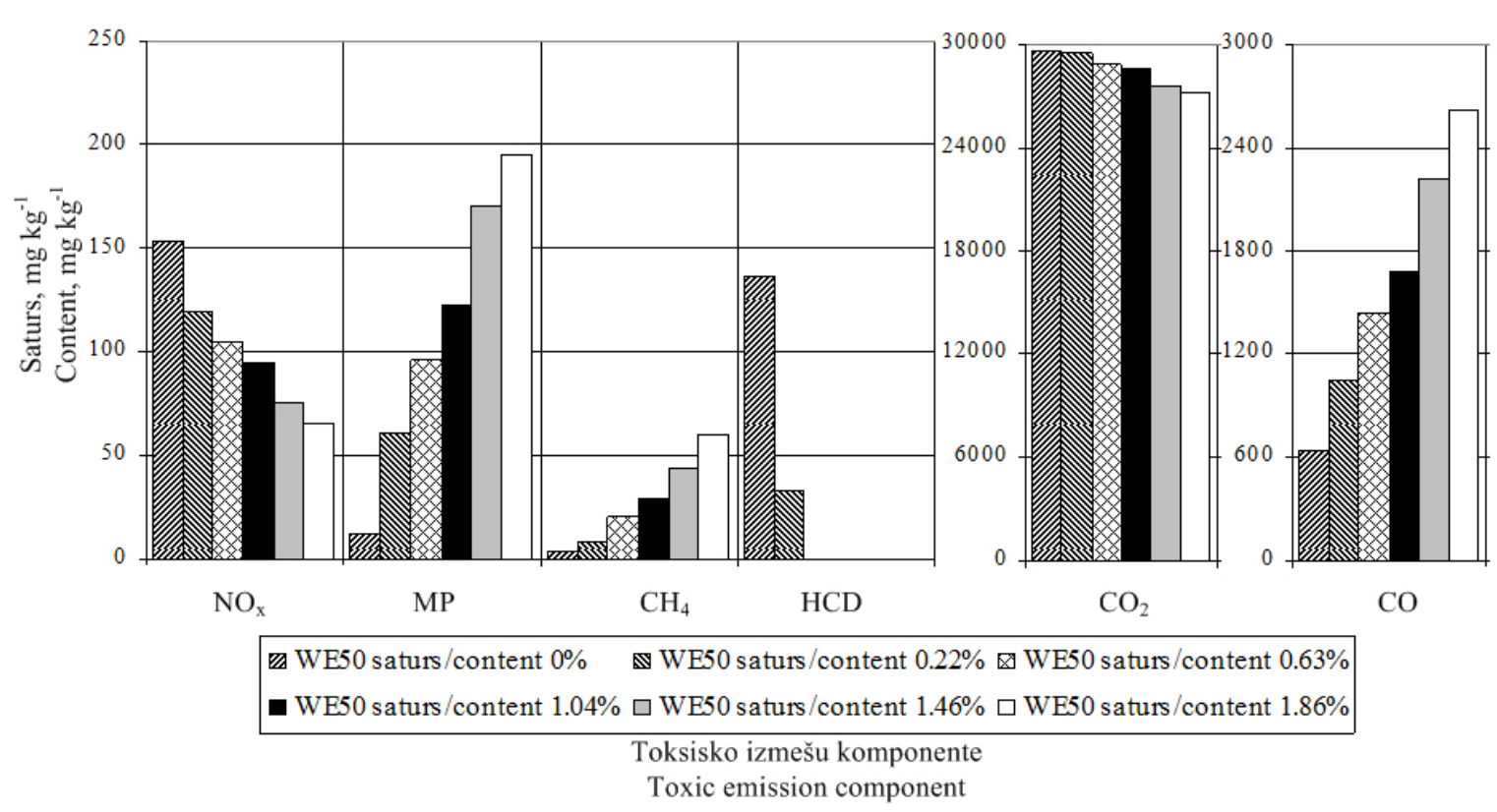

Paskaidrojums. MP - mehāniskās daḷiņas; HCD - dīzeḷmotoros nesadegušie og̣̣ūdeṇraži.

Explanation. MP - mechanical particles; HCD - hydrocarbons diesel.

4. att. Toksisko izmešu saturs atgāzēs pie $2500 \mathrm{~min}^{-1}$.

Fig. 4. The content of toxic emissions in exhaust gases at $2500 \mathrm{~min}^{-1}$.

Lai precizētu atgāzu izmaiṇu tendences dažādos WE50 padeves režīmos, pie $2500 \mathrm{~min}^{-1}$ motora kloķvārpstas apgriezieniem meklējumeksperimenti tika veikti ar WE50 saturu $0,0.22,0.63,1.04,1.46$ un $1.86 \%$ no ieplūstošā gaisa masas. Mērījumu rezultāti atspoguļoti 1. tabulā.

Toksisko izmešu daudzuma izmaiņu tendences atgāzēs, motoram veicot 2500 apgriezienus minūtē, bija līdzīgas tām tendencēm, kādas konstatēja pie $1500 \mathrm{~min}^{-1} . \mathrm{NO}_{\mathrm{x}}$ daudzums tika samazināts par $58 \%$, bet kopējais nesadegušo ogl̦ūdeņražu saturs, neskatoties uz metāna satura palielināšanos, tika samazināts līdz nullei. Šajā motora apgriezienu režīmā, palielinot WE50 piedevas daudzumu, izteikti samazinājās $\mathrm{CO}_{2}$ saturs atgāzēs (4. att.), taču $\mathrm{CO}$ un mehānisko daliṇu daudzums motora atgāzēs palielinājās 4-17 reizes, tāpēc, iesmidzinot $1.86 \%$ WE50 piejaukuma, mērījumi tika pārtraukti.

Pie motora apgriezieniem $2500 \mathrm{~min}^{-1}$ par efektīvāko tika konstatēts $0.63 \%$ WE50 piejaukums cilindrā ieplūstošajam gaisam, jo $\mathrm{NO}_{\mathrm{x}}$ saturs tika samazināts par $32 \%, \mathrm{CO}_{2}$ - par $3 \%$, bet nesadegušie ogḷūdeņraži atgāzēs vairs netika konstatēti.

Degvielas patēriņš tika noteikts ar precizitāti $0.1 \mathrm{~g}$, mērījumus nolasot ik pēc 3 sekundēm.

Motoram darbojoties ar $1500 \mathrm{~min}^{-1}$ un $2500 \mathrm{~min}^{-1}$ kloķvārpstas apgriezieniem un palielinot WE50 iesmidzināšanas daudzumu, tika novērotas līdzīgas degvielas patēriņa samazināšanās tendences. Degvielas patēriṇa diagrammas parādītas 5. un 6. attēlā.

Pie $1500 \mathrm{~min}^{-1}$ motora kloksvārpstas apgriezieniem degvielas patēriņšs samazinājās vidēji par 10\% uz katriem 10 g pievienotā WE50. N̦emot vērā, ka no izmešu emisijas viedokḷa pie 1500 min $^{-1}$ efektīvākais piejaukums ieplūdes gaisam ir $0.35 \%$ WE50, degvielas patērinšs tika samazināts par 0.11 litriem stundā jeb par $9 \%$.

Pie $2500 \mathrm{~min}^{-1}$ motora kloķvārpstas apgriezieniem degvielas patēriņš samazinājās vidēji par $6 \% \mathrm{uz}$ katriem 10 g pievienotā WE50. Pie efektīvākā WE50 piejaukuma ieplūdes gaisam šajā režīmā $(0.63 \%)$ degvielas patērinš̌ tika samazināts par $0.331 \mathrm{~h}^{-1}$ jeb par $16 \%$.

Šāds rezultāts izskaidrojams ar to, ka piedeva WE50 satur $50 \%$ bioetanola un līdz ar to tā darbojas kā papildu degviela. Tāpēc, palielinot WE50 iesmidzināšanu ieplūdes gaisam, degvielas patēriṇa samazinājums veido sakarību, kas tuva lineārai.

Ja ņem vērā globālo sasilšanu ietekmējošos faktorus, tad rapšu eḷıas kā degvielas pielietošana dīzel̦motoru darbināšanai ir viens no risinājumiem nelabvēlīgo klimata pārmaiņu samazināšanā, jo tā ir atjaunojamais resurss, un rapsis savā augšanas periodā uzņem daudz vairāk $\mathrm{CO}_{2}$ nekā motors izdala, sadedzinot rapšu elı̧u kā degvielu. Piedevas 


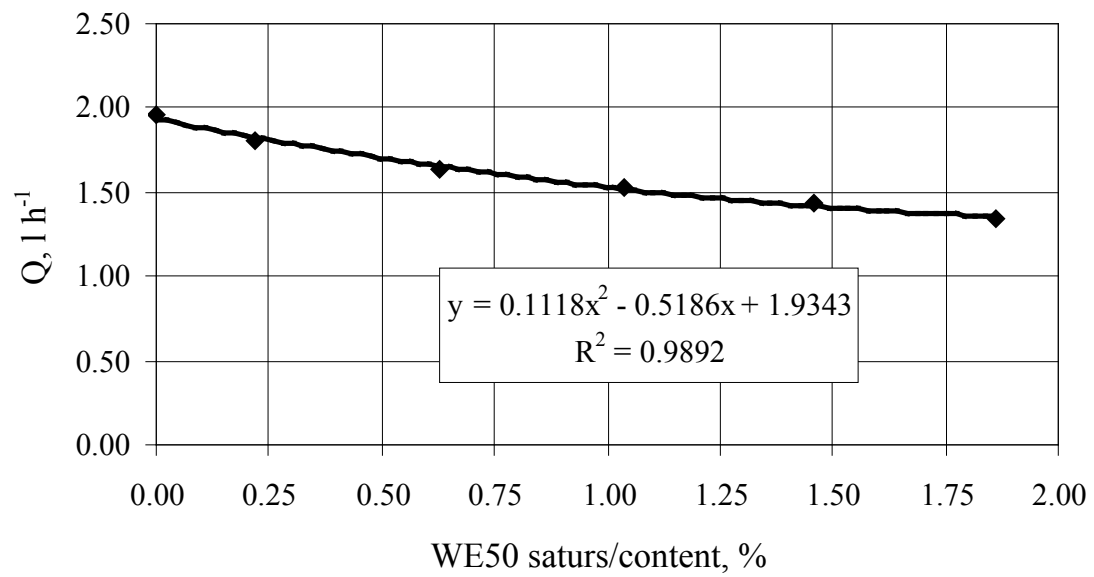

5. att. Degvielas patēriņa (Q) izmaiņas pie $1500 \mathrm{~min}^{-1}$.

Fig. 5. Fuel consumption (Q) changes at $1500 \mathrm{~min}^{-1}$.

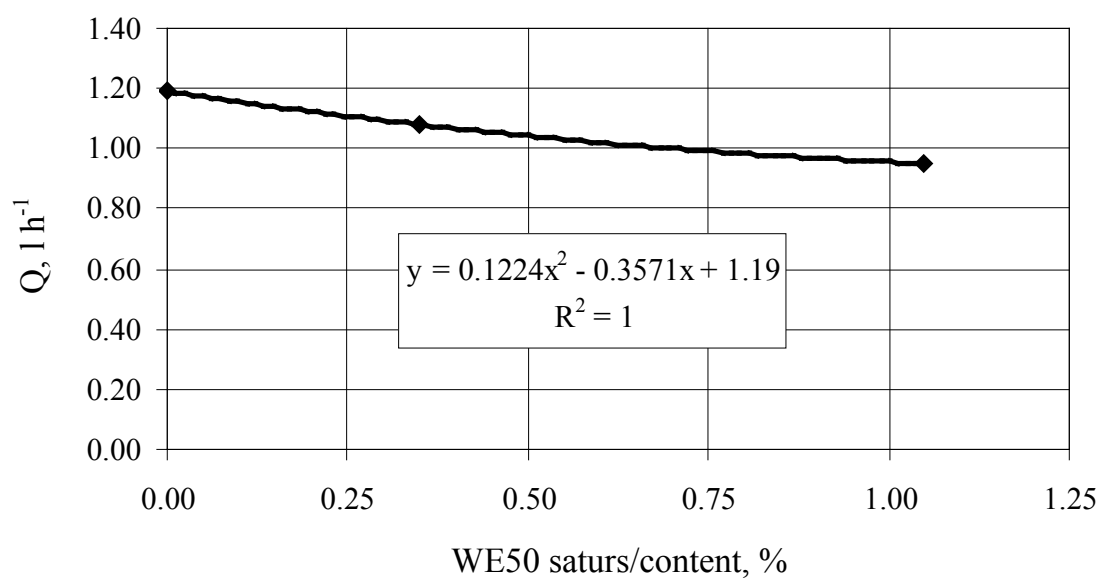

6. att. Degvielas patēriņa (Q) izmaiñas pie $2500 \mathrm{~min}^{-1}$.

Fig. 6. Fuel consumption (Q) changes at $2500 \mathrm{~min}^{-1}$.

WE50 izveidē arī izmantoti atjaunojamie resursi (bioetanols), un tās pielietošana veicina rapšu elııas degvielas izmešu sastāva normalizāciju, ietekmējot degvielas sadegšanas procesu motora cilindrā.

Tiešā veidā iegūtos rezultātus salīdzināt ar citu pētnieku darbiem ir sarežǵīti, jo līdz šim, lai panāktu $\mathrm{NO}_{\mathrm{x}}$ satura samazināšanu dīzel̦motoru atgāzēs, lietojot rapšu elı̧as degvielu, izmantota ūdens iesmidzināšana cilindrā (Markov, Bashirov, \& Gabitov, 2002). WE50 maisījuma izmantošana dod iespēju novērst ūdens iesmidzināšanas būtiskākos trūkumus - motora darbības nestabilitāti un pielietojuma problēmas ziemas apstākḷlos -, bet tendences degvielas patēriņa, kā arī $\mathrm{NO}_{\mathrm{x}}$ un nesadegušo ogḷūdeņražu samazināšanā atgāzēs ir vēl izteiktākas. Bioetanols rapšu el̦las degvielas izmantošanas efektivitātes uzlabošanai izmantots arī Lietuvā, tomēr tur bija atšķirīgs degmaisījuma sagatavošanas princips - bioetanols un benzīns (katrs $3.75 \%$ apjomā pēc tilpuma) tika piemaisīti rapšu ellıai jau tvertnē (Labeckas \& Slavinskas, 2010). Arī tāds degmaisījums dod iespēju to lietot zemākās gaisa temperatūrās, taču Lietuvā tika konstatēts būtisks $\mathrm{NO}_{\mathrm{x}}$ (līdz 27\%) palielinājums, salīdzinot ar tīru rapšu ellıu. Tādējādi WE50 maisījuma iesmidzināšana ieplūdes sistēmā ir efektīvāka.

\section{Secinājumi}

1. Izveidotais ūdens-bioetanola maisījums ir efektīvs līdzeklis, lai samazinātu $\mathrm{NO}_{\mathrm{x}}$ un kopējo nesadegušo oglūūeņražu daudzumu dīzel̦motoru atgāzēs, turklāt to var pielietot arī ziemas apstākļos.

2. Ūdens-bioetanola maisījuma iesmidzināšanas sistēma nav sarežğìta, un tās uzstādīšana neprasa būtisku dīzel̦motora pārbūvi. 
3. Ūdens-bioetanola maisījuma WE50 iesmidzināšanas sistēmai jābūt precīzai, jo pat pie nelielām maisījuma padeves daudzuma izmaiñām strauji mainās atgāzu sastāvs.

4. Pielietojot piedevu WE50, samazinās degvielas patēriņš, kas ir svarīgs faktors rapšu ellıas kā degvielas izmantošanas procesā, taču nepieciešams veikt precizējošus ekonomiskos aprēķinus par WE50 izgatavošanas izmaksām.

5. Gan rapšu eḷ̦as degviela, gan piedeva WE50 ir iegūtas no atjaunojamiem resursiem, un šim faktoram ir būtiska nozīme klimata pārmainu novēršanā.

\section{Literatūra}

1. AVL Emission Test Systems GmbH. (2007). AVL SESAM FTIR. User's Manual. Gaggenau, Germany: AVL Emission Test Systems GmbH.

2. Birkavs, A., \& Dukulis, I. (2011). Development of experimental equipment for vegetable oil fuel research. In 17th International Scientific Conference 'Research for Rural Development', Volume 1, 18-20 May 2011 (pp. 173-178). Jelgava, Latvia: Latvia University of Agriculture.

3. Dukulis, I., Birkavs, A., \& Birzietis, G. (2010). Investigation of flowability of rapeseed oil and diesel fuel blends in winter conditions. In Agricultural Engineering: International Scientific Conference 'Mobile Machines', 23-24 September 2010 (pp. 204-213). Kaunas, Lithuania: Lithuanian University of Agriculture.

4. Dukulis, I., Pirs, V., Jesko, Z., Birkavs, A., \& Birzietis, G. (2009). Testing of automobile VW Golf operating on three different fuels. In 8th International Scientific Conference 'Engineering for Rural Development', 28-29 May, 2009 (pp. 7-13). Jelgava, Latvia: Latvia University of Agriculture.

5. Hazar, H., \& Aydin, H. (2010). Performance and emission evaluation of a $\mathrm{CI}$ engine fueled with preheated raw rapeseed oil (RRO)-diesel blends. Applied Energy, 26, 786-790. DOI: 10.1016/j. apenergy.2009.05.021.

6. Kleinová, A., Vailing, I., Lábaj, J., Mikulec, J., \& Cvengroš, J. (2011). Vegetable oils and animal fats as alternative fuels for diesel engines with dual fuel operation. Fuel Processing Technology, 92, 1980-1986. DOI: 10.1016/j. fuproc.2011.05.018.
7. Labeckas, G., \& Slavinskas, S. (2005). Performance and exhaust emissions of directinjection diesel engine operating on rapeseed oil and its blends with diesel fuel. Transport, 5, 186-194.

8. Labeckas, G., \& Slavinskas, S. (2009). Performance and emission characteristics of off-road diesel engine operating on rapeseed oil and petrol blends. In 8th International Scientific Conference 'Engineering for Rural Development', 28-29 May, 2009 (pp. 135-140). Jelgava, Latvia: Latvia University of Agriculture.

9. Labeckas, G., \& Slavinskas, S. (2010). Analysis of performance and emissions of the exhausts of off-road diesel engine operating on three agent ethanol, petrol and rapeseed oil blend. In Agricultural Engineering: International Scientific Conference 'Mobile Machines', 23-24 September 2010 (pp. 91-104). Kaunas, Lithuania: Lithuanian University of Agriculture.

10. Markov, V.A., Bashirov R.M., \& Gabitov I.I. (2002). Toxicity of Diesel Engine Exhaust Emissions (2nd ed.). Moscow, Russia: Publishing House of Moscow State Technical University, NE Bauman (MSTU). (In Russian.)

11. Paulsen, H.M., Wichmann, V., Schuemann, U., \& Richter, B. (2011). Use of straight vegetable oil mixtures of rape and camelina as on farm fuels in agriculture. Biomass and Bioenergy, 35, 40154024. DOI: 10.1016/j.biombioe.2011.06.031.

12. Sidibe, S.S., Blin, J., Vaitilingom, G., \& Azoumah, Y. (2010). Use of crude filtered vegetable oil as a fuel in diesel engines state of the art: Literature review. Renewable and Sustainable Energy Reviews, 14, 2748-2759. DOI: 10.1016/j.rser.2010.06.018.

13. Soltic, P., Edenhauser, D., Thurnheer, T., Schreiber, D., \& Sankowski, A. (2009). Experimental investigation of mineral diesel fuel, GTL fuel, RME and neat soybean and rapeseed oil combustion in a heavy duty on-road engine with exhaust gas aftertreatment. Fuel, 8, 1-8. DOI: 10.1016/j.fuel.2008.07.028.

14. Thuneke, K. (2006). Rapeseed oil fuel Production, quality demands and use experience. In Biomass for Energy - Challenges for Agriculture, 25-26 September, 2006, Bruges, Belgium. Retrieved from http://www. northseabioenergy.org/files/17397/Klaus_ Thuneke.pdf. 